\title{
SISTEM PAKAR DIAGNOSA PENYAKIT DIABETES MELITUS
}

\author{
Adhiati Kusuma Wardani ${ }^{1}$, Nurudin Santoso ${ }^{2}$, Rosa Andrie Asmara ${ }^{3}$ \\ ${ }^{1}$ Program Studi Teknik Informatika, ${ }^{2,3}$ Jurusan Teknik Elektro, Politeknik Negeri Malang \\ 1e-mail: adhiati.kw@gmail.com, ${ }^{2}$ nurudin.santoso@gmail.com, ${ }^{3}$ rosaandrie@gmail.com
}

\begin{abstract}
Abstrak
Diabetes Melitus merupakan penyakit degeneratif yang diperkirakan terus meningkat. Permasalahan diagnosa penyakit Diabetes Melitus terletak pada bagaimana pengguna mengetahui kemungkinan tingkat resiko tipe dari penyakit Diabetes Melitus yang dialami. Masalah tersebut dapat diselesaikan dengan menerapkan sistem pakar. Sistem pakar yaitu suatu ilmu komputer yang berdasarkan kecerdasan buatan berguna untuk menyelesaikan masalah seperti yang biasa dilakukan para ahli. Berdasarkan pada permasalahan tersebut akan ditemukan beberapa diagnosa, sehingga menimbulkan ketidakkonsistenan. Penerapan metode Dempster Shafer pada sistem pakar dimanfaatkan untuk mengatasi ketidakkonsistenan. Dempster Shafer adalah suatu metode yang menerapkan fungsi kepercayaan dan pemikiran yang masuk akal. Nilai kepercayaan atau densitas terbesar menunjukkan hasil diagnosa penyakit Diabetes Melitus. Parameter penetapan diagnosa Diabetes Melitus dilihat berdasarkan hasil lab gula darah, umur, jenis kelamin, riwayat keluarga, dan gejala yang dialami. Hasil pengujian sistem yang menerapkan Dempster Shafer diperoleh tingkat akurasi sistem sebesar $86.7 \%$, sehingga sistem dignosa ini dapat menjadi alternatif solusi sebagai media konsultasi bagi pengguna untuk mendapatkan informasi kemungkinan tingkat resiko tipe pada penyakit Diabetes Melitus yang dialami.
\end{abstract}

\section{Kata kunci : Sistem Pakar, Dempster Shafer, Diabetes Melitus}

\section{Pendahuluan}

Menurut American Diabetes Association (ADA) 2005, Diabetes Melitus (DM) merupakan suatu kelompok penyakit metabolik dengan karakteristik hiperglikemia yang terjadi karena kelainan sekresi insulin, kerja insulin atau keduaduanya. Diabetes Melitus karena sifat penyakitnya yang kronik dan bisa menangani seluruh bagian tubuh memerlukan pendekatan yang melibatkan berbagai pihak, seperti medis, keluarga, serta masyarakat. Sebagai alternatif solusi dengan memanfaatkan kemajuan ilmu pengetahuan dan teknologi informasi saat ini sistem yang dirancang dapat dijadikan sebagai media informasi untuk mengetahui terserang tidaknya penyakit DM, sehingga dapat segera dilakukan penanganan lebih lanjut dengan melakukan konsultasi ke dokter. Salah satu teknologi informasi yang dapat dimanfaatkan adalah mengembangkan sistem pakar untuk mendiagnosa tipe penyakit DM berdasarkan gejala-gejala yang dialami user.

Sistem pakar adalah suatu cabang dari disiplin ilmu komputer yang berdasarkan kecerdasan buatan (Artificial Intelligence) yang mengadopsi pengetahuan manusia ke komputer, agar komputer dapat menyelesaikan masalah seperti yang biasa dilakukan para ahli (Kusumadewi, 2003:109). Guna mengetahui tingkat penyakit DM, maka dibuat sistem pakar diagnosa Diabetes berbasis web dengan Metode Dempster Shafer. Teori Dempster Shafer adalah suatu teori matematika untuk pembuktian berdasarkan belief functions and plausible reasoning (fungsi kepercayaan dan pemikiran yang masuk akal), yang digunakan untuk mengkombinasikan potongan informasi yang terpisah (bukti) untuk mengkalkulasi kemungkinan dari suatu peristiwa. Dalam menghadapi suatu permasalahan, sering ditemukan jawaban yang tidak memiliki kepastian penuh. Ketidakpastian ini dapat berupa hasil suatu kejadian. Sehingga digunakan metode Dempster Shafer sebagai metode untuk mengatasi ketidakkonsistenan.

Pada analisa permasalahannya, tipe penyakit DM dapat didiagnosa berdasarkan data fakta ataupun gejala yang dialami pengguna sistem. Dengan memperhatikan data fakta ataupun gejala-gejala yang dialami, diharapkan sistem ini dapat mendiagnosa tipe pada penyakit DM, sehingga gangguan atau penyakit dapat terdeteksi lebih awal dan penanganan terhadap keluhan tersebut dapat segera dilakukan.

\section{Metode}

Metode yang digunakan dalam penelitian ini mengacu pada konsep metode penelitian Waterfall. Konsep sistem pakar dengan basis pengetahuan dilakukan sesuai langkah-langkah sesuai metode penelitian tersebut meliputi pengumpulan studi literatur dan data, analisa kebutuhan, perancangan sistem, implementasi sistem, dan pengujian sistem. Analisis dan perancangan sistem yang dibuat meliputi WBS (Work Breakdown Structure), Basis data, Flowchart Diagram, Usecase, ERD (Entity Relationship Diagram), Diagram Konteks dan Data Flow Diagram (DFD). Mesin inferensi adalah sebuah program yang berfungsi untuk memandu proses penalaran terhadap suatu kondisi berdasarkan pada 
basis pengetahuan yang ada, memanipulasi dan mengarahkan kaidah, model, dan fakta yang disimpan dalam basis pengetahuan untuk mencapai solusi atau kesimpulan. Konsep mesin inferensi menggunakan Forward Chaining yang akan mengolah bobot pada tiap gejala yang dimasukkan user menggunakan metode Dempster Shafer. Output antarmuka yang dihasilkan adalah nilai kepercayaan terbesar dari perhitungan Dempster Shafer dan pengembangan sistem ini dibangun menggunakan PHP dan MySQL.

\section{a. Metode Dempster Shafer}

Algoritma Dempster Shafer adalah adalah suatu teori matematika untuk pembuktian berdasarkan belief functions and plausible reasoning (fungsi kepercayaan dan pemikiran yang masuk akal), yang digunakan untuk mengkombinasikan potongan informasi yang terpisah (bukti) untuk mengkalkulasi kemungkinan dari suatu peristiwa. Teori ini dikembangkan oleh Untuk mengatasi ketidakkonsistenan, maka dapat menggunakan penalaran dengan teori Dempster Shafer. Secara umum teori Dempster Shafer ditulis dalam suatu interval:

\section{[Belief,Plausibility]}

Belief (Bel) adalah ukuran kekuatan evidence dalam mendukung suatu hipotesa, jika bernilai 0 maka mengindikasi bahwa tidak ada evidence, dan jika bernilai 1 menunjukkan adanya kepastian atau Plausibility (PI), yang dinotasikan sebagai berikut :

$\mathrm{PI}(\mathrm{H})=1-\operatorname{Bel}(-\mathrm{H})$

Plausibility juga bernilai 0 sampai 1. Jika yakin akan $-\mathrm{H}$, maka dapat dikatakan bahwa $\operatorname{Bel}(-\mathrm{H})=1$, dan $\mathrm{PI}(\ulcorner\mathrm{H})=0$. Pada teori Dempster Shafer dikenal adanya frame of discrement yang dinotasikan dengan $\theta$. Frame ini merupakan semesta pembicaraan dari sekumpulan hipotesis. Tujuannya adalah mengaitkan ukuran kepercayaan elemenelemen $\theta$. Tidak semua evidence secara langsung mendukung tiap-tiap elemen. Untuk itu perlu adanya probabilitas fungsi densitas (m). Nilai m tidak hanya mendefinisikan elemen-elemen $\theta$ saja, namun juga semua subsetnya. Sehingga jika $\theta$ berisi $n$ elemen, maka subset $\theta$ adalah $2^{\mathrm{n}}$. Jumlah semua $\mathrm{m}$ dalam subset $\theta$ sama dengan 1. Apabila tidak ada informasi apapun untuk memilih hipotesis, maka nilai $: \operatorname{m}\{\theta\}=$ 1,0 .

Apabila diketahui $\mathrm{X}$ adalah subset dari $\theta$, dengan $\mathrm{m}_{1}$ sebagai fungsi densitasnya, dan $\mathrm{Y}$ juga merupakan subset dari $\theta$ dengan $\mathrm{m}_{2}$ sebagai fungsi densitasnya, maka dapat dibentuk fungsi kombinasi $m_{1}$ dan $m_{2}$ sebagai $m_{3}$, dengan rumus seperti pada persamaan 2 berikut :

$$
m_{n}(z)=\frac{\sum_{x \cap y=z} m_{1}(X) \cdot m_{2}(Y)}{1-\sum_{x \cap y=\phi} m_{1}(X) \cdot m_{2}(Y)}
$$

Dimana :

$\mathrm{m}_{\mathrm{n}}(\mathrm{Z})=$ mass function dari evidence $(\mathrm{Z})$

$\mathrm{m}_{1}(\mathrm{X})=$ mass function dari evidence $(\mathrm{X})$

$\mathrm{m}_{2}(\mathrm{Y})=$ mass function dari evidence $(\mathrm{Y})$

$\mathrm{Z} \mathrm{m}_{3}(\mathrm{X}) \cdot \mathrm{m}_{2}(\mathrm{Y})=$ ada hasil irisan dari $\mathrm{m}_{1}$ dan $\mathrm{m}_{2}$ $\varnothing \mathrm{Z} \mathrm{m}_{1}(\mathrm{X}) \cdot \mathrm{m}_{2}(\mathrm{Y})=$ tidak ada hasil irisan (irisan kosong $(\varnothing))$

\section{Hasil}

a. Arsitektur Sistem Pakar

Sistem pakar yaitu suatu cabang dari disiplin ilmu komputer yang berdasarkan kecerdasan buatan (Artificial Intelligence) yang mengadopsi pengetahuan manusia ke komputer, agar komputer dapat menyelesaikan masalah seperti yang biasa dilakukan para ahli. Sistem pakar terdiri dari 3 komponen utama, yaitu basis pengetahuan (knowledge base), mesin inferensi (inference engine), dan antarmuka ( user interface).

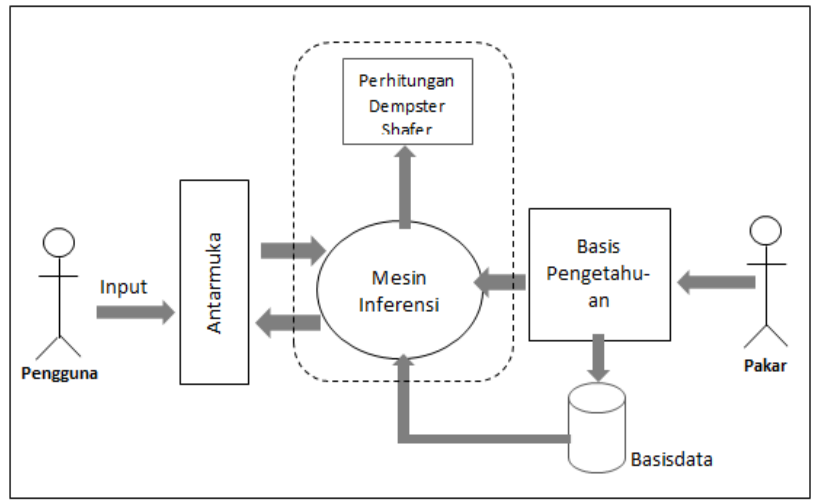

Gambar 1 Blok diagram kerangka sistem

b. Perancangan Basis Pengetahuan

Basis pengetahuan berisi pengetahuanpengetahuan yang diperlukan untuk memahami, memformulasikan, dan menyelesaikan masalah

Tabel 1 Gejala pada tipe Penyakit DM

\begin{tabular}{|c|l|c|c|c|}
\hline No & \multicolumn{1}{|c|}{ Keterangan } & $\begin{array}{c}\text { D } \\
\text { M } \\
\mathbf{1}\end{array}$ & $\begin{array}{c}\text { D } \\
\text { M }\end{array}$ & $\begin{array}{c}\text { D } \\
\text { G }\end{array}$ \\
\hline 1 & $\begin{array}{l}\text { Polyuri (sering buang air } \\
\text { kecil) }\end{array}$ & $\sqrt{ }$ & $\sqrt{ }$ & $\sqrt{ }$ \\
\hline 2 & $\begin{array}{l}\text { Polyfagi (mudah merasa } \\
\text { lapar) }\end{array}$ & $\sqrt{ }$ & $\sqrt{ }$ & $\sqrt{ }$ \\
\hline 3 & $\begin{array}{l}\text { Polydipsi (mudah merasa } \\
\text { haus) }\end{array}$ & $\sqrt{ }$ & $\sqrt{ }$ & $\sqrt{ }$ \\
\hline 4 & \begin{tabular}{l} 
Lemah \\
\hline 5
\end{tabular} & $\sqrt{ }$ & $\sqrt{ }$ & $\sqrt{ }$ \\
\hline 6 & Kesemutan & $\sqrt{ }$ & $\sqrt{ }$ & $\sqrt{ }$ \\
\hline 7 & Muntah & $\sqrt{ }$ & $\sqrt{ }$ & $\sqrt{ }$ \\
\hline 8 & Luka & $\sqrt{ }$ & $\sqrt{ }$ \\
\hline 9 & Riwayat DM pada keluarga & $\sqrt{ }$ & $\sqrt{ }$ & $\sqrt{ }$ \\
\hline
\end{tabular}




\begin{tabular}{|c|l|c|c|c|}
\hline 10 & Mata Kabur & $\sqrt{ }$ & $\sqrt{ }$ & $\sqrt{ }$ \\
\hline 11 & Pusing & $\sqrt{ }$ & $\sqrt{ }$ & $\sqrt{ }$ \\
\hline 12 & Sesak nafas & $\sqrt{ }$ & $\sqrt{ }$ & \\
\hline 13 & Pucat & $\sqrt{ }$ & $\sqrt{ }$ & \\
\hline 14 & Batuk & & $\sqrt{ }$ & \\
\hline 15 & $\begin{array}{l}\text { Hambatan kualitas } \\
\text { berhubungan pasangan } \\
\text { suami istri }\end{array}$ & & $\sqrt{ }$ & \\
\hline 16 & Badan menjadi kurus & $\sqrt{ }$ & $\sqrt{ }$ & \\
\hline 17 & $\begin{array}{l}\text { Riwayat melahirkan bayi } \\
\text { lebih dari 4 kg }\end{array}$ & & & $\sqrt{ }$ \\
\hline 18 & Hamil & & & $\sqrt{ }$ \\
\hline
\end{tabular}

Basis pengetahuan yang digunakan yaitu dengan rule-based reasoning (penalaran berbasis aturan), pada penalaran berbasis aturan, pengetahuan direpresentasikan dengan menggunakan aturan berbentuk IF-THEN. Beberapa aturan yang digunakan dalam menegakkan diagnosa tipe pada penyakit Diabetes Melitus (DM) meliputi hasil laboratorium gula darah, umur, jenis kelamin dan gejala-gejala yang dialami. Aturan tersebut diambil dari pengetahuan seorang pakar dan ditunjang dengan berbagai referensi maupun literatur lainnya. Berdasarkan berbagai sumber tersebut, maka aturanaturan yang dapat dibentuk adalah sebagai berikut :

1. IF Gdp $\geq 126 \mathrm{mg} / \mathrm{dl}$ AND Gds $\geq 200 \mathrm{mg} / \mathrm{dl}$ AND $\mathrm{Gd} 2 \mathrm{pp} \geq 200 \mathrm{mg} / \mathrm{dl}$ AND umur $\leq 30$ tahun AND jenis kelamin $=$ pria OR wanita AND riwayat DM keluarga AND gejala-gejala DM Tipe I THEN Diabetes Tipe I

2. IF Gdp $\geq 126 \mathrm{mg} / \mathrm{dl}$ AND Gds $\geq 200 \mathrm{mg} / \mathrm{dl}$ AND $\mathrm{Gd} 2 \mathrm{pp} \geq 200 \mathrm{mg} / \mathrm{dl}$ AND umur $\geq 30$ tahun AND jenis kelamin $=$ pria $\mathrm{OR}$ wanita $\mathrm{AND}$ riwayat $\mathrm{DM}$ keluarga AND gejala-gejala DM Tipe 2 THEN Diabetes Tipe II

3. IF Gdp $\geq 126 \mathrm{mg} / \mathrm{dl}$ AND Gds $\geq 200 \mathrm{mg} / \mathrm{dl}$ AND Gd2pp $\geq 200 \mathrm{mg} / \mathrm{dl}$ AND umur $\geq 30$ tahun AND Jenis Kelamin $=$ wanita(hamil) AND riwayat DM keluarga AND gejala-gejala DMG THEN Diabetes Melitus Gestasional (DMG)

Keterangan :

Gdp : Gula darah puasa

Gds : Gula darah sesaat

Gd2pp :Gula darah 2 jam setelah makan (postprandial)

c. Perancangan Basis Data

Basis data dibuat menggunakan MySQL. Dalam perancangan sistem pakar ini dibuat 7 tabel untuk menyimpan data yang sudah diproses.

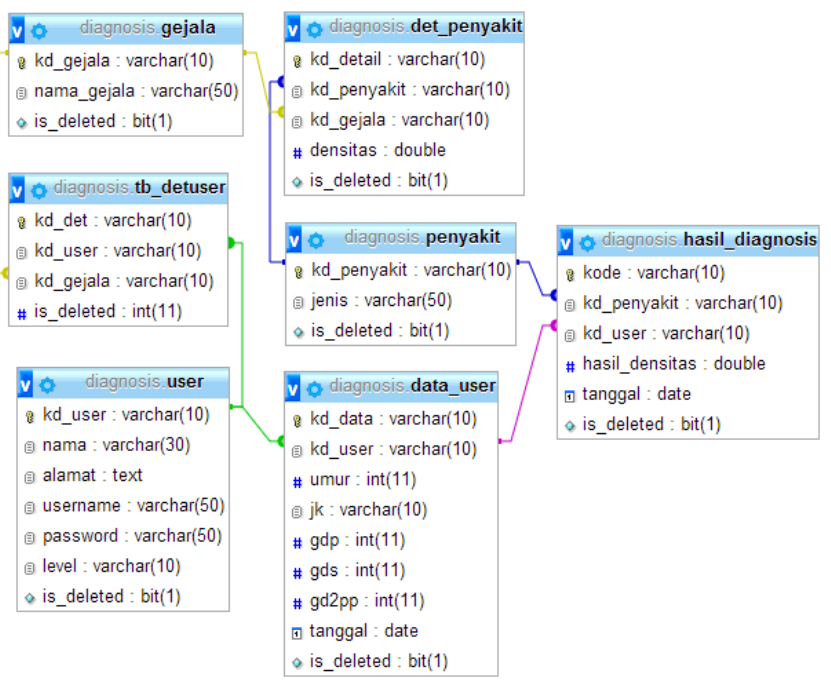

Gambar 2 Perancangan basis data

\section{d. Flowchart Sistem}

Flowchart sistem merupakan diagram alur proses berjalannya sistem diagnosa DM dengan menerapkan metode Dempster Shafer. Berikut perancangan flowchart sistem :

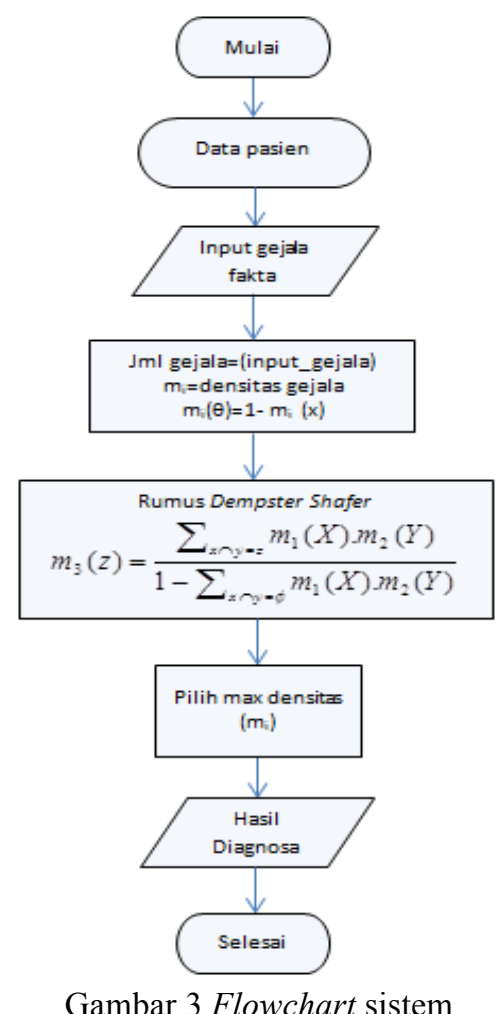

e. Flowchart Mesin Inferensi

Mesin inferensi adalah sebuah program yang berfungsi untuk memandu proses penalaran terhadap suatu kondisi berdasarkan pada basis pengetahuan. Berikut adalah flowchart mesin inferensi menjelaskan tentang alur proses metode Dempster Shafer. 


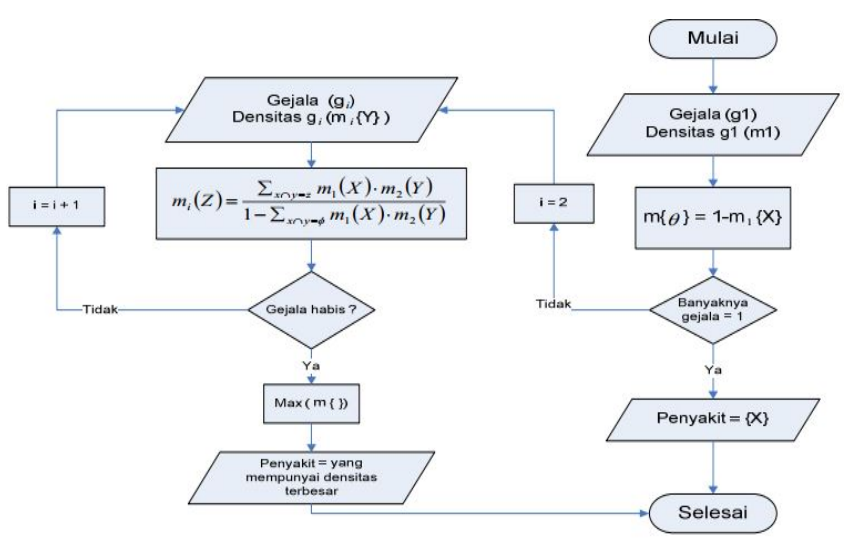

Gambar 4 Flowchart Mesin Inferensi

\section{Pembahasan}

a. Pengujian Sistem

Untuk mengetahui hasil diagnosa penyakit DM, maka dilakukan pengujian proses diagnosa. Proses pengujian sistem berupa masukan data gejala dan data fakta oleh pengguna. Setelah proses diagnosa berhasil dilakukan, maka sistem akan menampilkan hasil diagnosa berupa kemungkinan tipe penyakit DM yang diderita disertai dengan persentase besarnya kepercayaan terhadap kemungkinan penyakit tersebut. Berikut pengujian data pertama dapat dilihat pada gambar 4 :
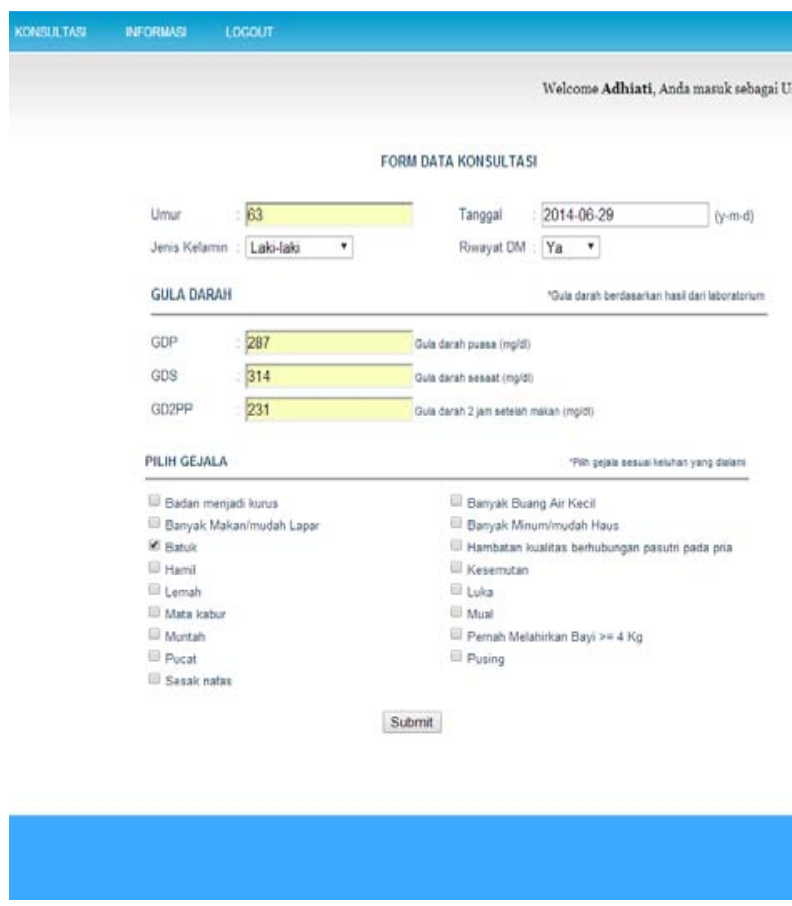

Gambar 4 Form input data konsultasi

Setelah pengguna memasukkan data, maka sistem akan memproses. Keluaran yang dihasilkan adalah hasil diagnosa berupa tipe penyakit DM dan besarnya nilai kepercayaan berdasarkan perhitungan dengan Demsptser Shafer. Berikut hasil diagnosa (output) yang dihasilkan :

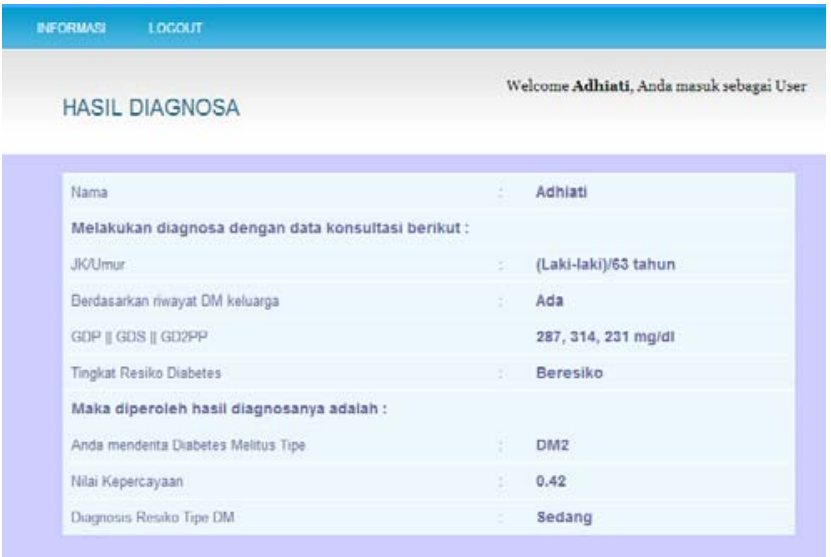

Gambar 5 Output hasil diagnosa

b. Analisa perhitungan Dempster Shafer

Berdasarkan pengujian sistem di atas, berikut analisa perhitungan data masukan dengan metode Dempster Shafer :

Penyelesaian :

Langkah 1 : gula darah puasa $(>126 \mathrm{mg} / \mathrm{dl})$

Gdp $>126$ mg/dl merupakan diagnosa DM untuk DM1, DM2, dan DMG.

$$
\begin{aligned}
& m_{1}(g d p)=0.7 \\
& m_{1}(\theta)=1-m_{1}(g d p)=1-0.7=0.3
\end{aligned}
$$

Langkah 2 : gula darah sesaat $(>200 \mathrm{mg} / \mathrm{dl})$

Kemudian ada fakta baru, yaitu Gdp $>200$ $\mathrm{mg} / \mathrm{dl}$ merupakan diagnosa DM untuk DM1, DM2, dan DMG.

$$
\begin{aligned}
& m_{2}(g d s)=0.7 \\
& m_{2}(\theta)=1-m_{2}(g d s)=1-0.7=0.3
\end{aligned}
$$

\begin{tabular}{|c|c|c|}
\hline & $\begin{array}{r}m_{2}(\mathrm{DM} 1, \mathrm{DM} 2, \\
\mathrm{DMG})\end{array}$ & $\begin{array}{r}m_{2}(\theta) \\
0.3\end{array}$ \\
\hline $\begin{array}{r}m_{1}(\mathrm{DM} 1, \\
\mathrm{DM} 2, \mathrm{DMG}) \\
0.7 \\
\end{array}$ & $\begin{array}{cr}\text { (DM1,DM2, } \\
\text { DMG) }\end{array}$ & $\begin{array}{l}\text { (DM1,DM2, } \\
\text { DMG) } 0.21\end{array}$ \\
\hline $\begin{array}{r}m_{1}(\theta) \\
0.3\end{array}$ & $\begin{array}{lr}\text { (DM1,DM2, } \\
\text { DMG) } & 0.21\end{array}$ & $\begin{array}{r}\boldsymbol{\theta} \\
0.09\end{array}$ \\
\hline
\end{tabular}

Maka, selanjutnya menghitung nilai keyakinan terhadap 2 gejala tersebut, sebagai berikut :

$$
\begin{aligned}
& m_{3}(\mathrm{DM} 1, \mathrm{DM} 2, \mathrm{DMG})=\frac{0.49+0.21+}{\underline{0.21}} \\
& =0.911-0 \\
& m_{3}(\theta)=\underline{0.09}=0.09
\end{aligned}
$$

Langkah 3 : gula darah 2 jam setelah makan $(>200$ $\mathrm{mg} / \mathrm{dl})$

Gd2pp $>200$ mg/dl merupakan diagnosa DM untuk DM1, DM2, dan DMG. 


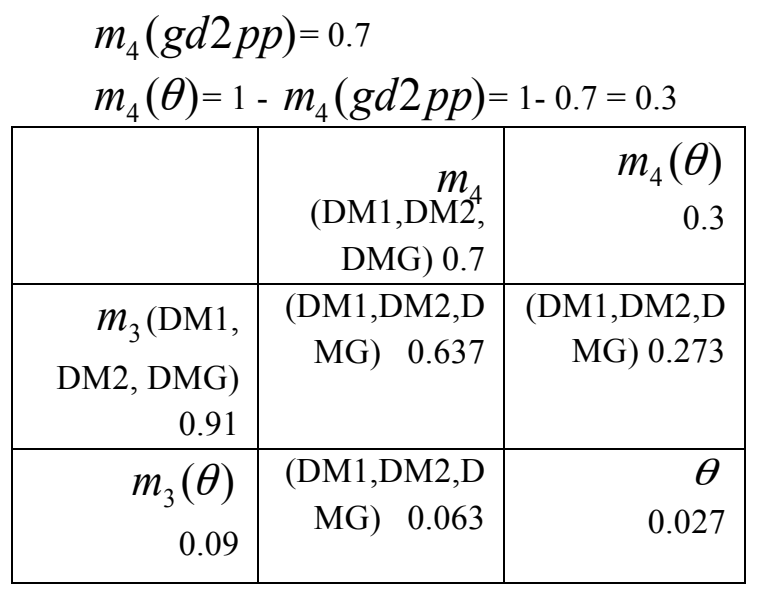

$$
\begin{gathered}
m_{5}(\mathrm{DM} 1, \mathrm{DM} 2, \mathrm{DMG})=\frac{0.637+0.063+0.273}{1-0} \\
=0.973 \\
m_{5}(\boldsymbol{\theta})=\underline{0.027}=0.027 \\
1-0
\end{gathered}
$$

\begin{tabular}{|c|c|c|}
\hline \multicolumn{3}{|c|}{$\begin{array}{l}m_{6}(\text { umur })=0.7 \\
m_{6}(\theta)=1-m_{6}(\varepsilon\end{array}$} \\
\hline & $\begin{array}{r}m_{6} \\
(\mathrm{DM} 2, \mathrm{DMG}) \\
0.7\end{array}$ & $\begin{array}{r}m_{6}(\theta) \\
0.3\end{array}$ \\
\hline $\begin{array}{r}m_{5}(\mathrm{DM} 1, \\
\mathrm{DM} 2, \mathrm{DMG}) \\
0.973\end{array}$ & $\begin{array}{r}\text { (DM2,DMG) } \\
0.6811\end{array}$ & $\begin{array}{r}\text { (DM1,DM2,D } \\
\text { MG) } 0.2919\end{array}$ \\
\hline $\begin{array}{r}m_{5}(\theta) \\
0.027\end{array}$ & $\begin{array}{r}(\mathrm{DM} 2, \mathrm{DMG}) \\
0.0189\end{array}$ & $\begin{array}{r}\boldsymbol{\theta} \\
0.0081\end{array}$ \\
\hline
\end{tabular}

Langkah 4 : umur ( $>30$ tahun)

Umur $>30$ tahun merupakan diagnosa DM untuk DM2 dan DMG.

$$
\begin{aligned}
& m_{7}(\mathrm{DM} 1, \mathrm{DM} 2, \mathrm{DMG})=\frac{0.2919}{1-0}=0.2919 \\
& m_{7}(\mathrm{DM} 2, \mathrm{DMG})=\frac{0.6811+0.0189}{1-0}=0.7 \\
& m_{7}(\theta)=\frac{0.0081}{1-0}=0.0081
\end{aligned}
$$

\begin{tabular}{|c|c|c|}
\hline \multicolumn{3}{|c|}{$\begin{array}{l}m_{8}(\text { umur })=0.5 \\
m_{8}(\theta)=1-m_{8}(\text { umur })=1-0.5=0.5\end{array}$} \\
\hline & $\begin{array}{r}m_{8} \\
(\mathrm{DM} 1, \mathrm{DM} 2) \\
0.5\end{array}$ & $\begin{array}{r}m_{8}(\theta) \\
0.5\end{array}$ \\
\hline$m_{7}(\mathrm{DM} 1$ & (DM1,DM2) & (DM1,DM2,D \\
\hline
\end{tabular}

Langkah 5 : jenis kelamin pria

Jenis kelamin pria merupakan diagnosa DM

\begin{tabular}{|c|c|c|}
\hline & $\begin{array}{rr} & m_{10} \\
(\mathrm{DM} 1, \mathrm{DM} 2, \mathrm{DM} \\
\mathrm{G}) & 0.7\end{array}$ & $\begin{array}{r}m_{10}(\theta) \\
0.3\end{array}$ \\
\hline $\begin{array}{r}m_{9}(\mathrm{DM} 1, \\
\mathrm{DM} 2, \mathrm{DMG}) \\
01459\end{array}$ & $\begin{array}{r}\text { (DM1,DM2,DM } \\
\text { G) } \quad 0.1021\end{array}$ & $\begin{array}{r}\text { (DM1,DM2,D } \\
\text { MG) } 0.0437\end{array}$ \\
\hline $\begin{array}{r}m_{9}(\mathrm{DM} 1, \\
\mathrm{DM} 2) \\
0.15\end{array}$ & $\begin{array}{r}\text { (DM1, DM2) } \\
0.105\end{array}$ & $\begin{array}{r}\text { (DM1, DM2) } \\
0.045\end{array}$ \\
\hline $\begin{array}{r}m_{9}(\mathrm{DM} 2, \\
\mathrm{DMG}) \\
0.35\end{array}$ & $\begin{array}{r}\text { (DM2,DMG) } \\
0.245\end{array}$ & $\begin{array}{r}\text { (DM2, DMG) } \\
0.105\end{array}$ \\
\hline $\begin{array}{r}m_{9}(\mathrm{DM} 2) \\
0.35\end{array}$ & $\begin{array}{r}(\mathrm{DM} 2) \\
0.245\end{array}$ & $\begin{array}{r}\text { (DM2) } \\
0.105\end{array}$ \\
\hline $\begin{array}{r}m_{9}(\theta) \\
0.0041\end{array}$ & $\begin{array}{r}\text { (DM1,DM2,DM } \\
\text { G) } 0.0028\end{array}$ & $\begin{array}{r}\boldsymbol{\theta} \\
0.0012\end{array}$ \\
\hline
\end{tabular}
untuk DM1 dan DM2.

\begin{tabular}{|r|r|r|}
\hline $\mathrm{DM} 2, \mathrm{DMG})$ & 0.1459 & $\mathrm{MG}) 0.1459$ \\
0.2919 & & \\
\hline$m_{7}(\mathrm{DM} 2$, & $(\mathrm{DM} 2)$ & $(\mathrm{DM} 2, \mathrm{DMG})$ \\
$\mathrm{DMG})$ & 0.35 & 0.35 \\
0.7 & & \\
\hline$m_{7}(\theta)$ & $(\mathrm{DM} 1, \mathrm{DM} 2)$ & $\boldsymbol{\theta}$ \\
0.0081 & 0.0041 & 0.0041 \\
\hline
\end{tabular}

$$
\begin{aligned}
& m_{9}(\mathrm{DM} 1, \mathrm{DM} 2, \mathrm{DMG})=\frac{0.1459}{1-0}=0.1459 \\
& m_{9}(\mathrm{DM} 1, \mathrm{DM} 2)=\frac{0.1459+0.0041}{1-0}=0.15 \\
& m_{9}(\mathrm{DM} 2, \mathrm{DMG})=\frac{0.35}{1-0}=0.35 \\
& m_{9}(\mathrm{DM} 2)=\underline{0.35}=0.35 \\
& m_{9}(\theta)=\frac{0.0041}{1-0}=0.0041
\end{aligned}
$$

Langkah 6 : ada riwayat DM pada keluarga Ada riwayat DM pada keluarga merupakan diagnosa DM untuk DM1, DM2, dan DMG.

$$
\begin{aligned}
& m_{10}(\text { riwayat })=0.7 \\
& m_{10}(\theta)=1-m_{10}(\text { riwayat })=1-0.3= \\
& 0.3
\end{aligned}
$$

$m_{11}(\mathrm{DM} 1, \mathrm{DM} 2, \mathrm{DMG})=$

$\frac{0.1021+0.0028+0.0437}{1-0}=0.1486$ 


$$
\begin{aligned}
& m_{11}(\mathrm{DM} 1, \mathrm{DM} 2)=\frac{0.105+0.045}{1-0}=0.15 \\
& m_{11}(\mathrm{DM} 2, \mathrm{DMG})=\frac{0.245+0.105}{1-0}=0.35 \\
& m_{11}(\mathrm{DM} 2)=\frac{0.245+0.105}{1-0}=0.35 \\
& m_{11}(\theta)=\frac{0.0012}{1-0}=0.0012
\end{aligned}
$$

Langkah 7 : gejala batuk

Gejala batuk merupakan diagnosa DM untuk DM1, DM2, dan DMG.

\begin{tabular}{|r|r|r|}
\multicolumn{2}{|c}{$m_{12}($ batuk $)=0.3$} \\
$m_{12}(\theta)=1-m_{12}($ batuk $)=1$ & $-0.3=0.7$ \\
& $m_{12}$ & $m_{12}(\theta)$ \\
& $(\mathrm{DM} 1, \mathrm{DM} 2$, & 0.7 \\
& $\mathrm{DMG})$ & \\
& 0.3 & \\
\hline$m_{11}(\mathrm{DM} 1$, & $(\mathrm{DM} 1, \mathrm{DM} 2, \mathrm{D}$ & $(\mathrm{DM} 1, \mathrm{DM} 2, \mathrm{D}$ \\
$\mathrm{DM} 2, \mathrm{DMG})$ & $\mathrm{MG})$ & $\mathrm{MG}) 0.1337$ \\
0.1486 & 0.0446 & \\
\hline$m_{11}(\mathrm{DM} 1$, & $(\mathrm{DM} 1, \mathrm{DM} 2)$ & $(\mathrm{DM} 1, \mathrm{DM} 2)$ \\
$\mathrm{DM} 2)$ & 0.045 & 0.135 \\
0.15 & & \\
\hline$m_{11}(\mathrm{DM} 2$, & $(\mathrm{DM} 2, \mathrm{DMG})$ & $(\mathrm{DM} 2, \mathrm{DMG})$ \\
$\mathrm{DMG})$ & 0.105 & 0.315 \\
0.35 & & \\
\hline$m_{11}(\mathrm{DM} 2)$ & $(\mathrm{DM} 2)$ & $(\mathrm{DM} 2)$ \\
0.35 & 0.105 & 0.315 \\
\hline$m_{11}(\theta)$ & $(\mathrm{DM} 1, \mathrm{DM} 2$, & 0.00084 \\
0.0012 & $\mathrm{DMG})$ & \\
\hline
\end{tabular}

$$
\begin{aligned}
& \begin{array}{c}
m_{11}(\mathrm{DM} 1, \mathrm{DM} 2, \mathrm{DMG})=\frac{0.0446+0.1337}{1-0} \\
=0.1783
\end{array} \\
& m_{11}(\mathrm{DM} 1, \mathrm{DM} 2)=\frac{0.045+0.135}{1-0}=0.15 \\
& m_{11}(\mathrm{DM} 2, \mathrm{DMG})=\frac{0.105+0.315}{1-0}=0.42 \\
& m_{11}(\mathrm{DM} 2)=\frac{0.105+0.315}{1-0}=\mathbf{0 . 4 2} \\
& m_{11}(\theta)=\frac{0.00084}{1-0}=0.00084
\end{aligned}
$$

Dari perhitungan dari gejala-gejala di atas yaitu gdp $>126$, gds $>200$, gd2pp $>200$, umur $>30$ tahun, jenis kelamin pria, mempunyai riwayat DM pada keluarga, dan gejala batuk, maka diperoleh nilai keyakinan paling kuat adalah terhadap penyakit DM Tipe 2, yaitu sebesar 0.42 .

\section{Kesimpulan dan Saran}

5.1 Kesimpulan

Berdasar pada hasil perancangan, implementasi dan pengujian terhadap sistem aplikasi yang sudah dibuat, diperoleh kesimpulan sebagai berikut :

1.Penerapan basis pengetahuan (knowledgde base) dan mesin inferensi dapat digunakan untuk membangun suatu sistem pakar berbasis web untuk diagnosa penyakit Diabetes Mellitus berdasarkan pada beberapa fakta dan gejala yang dialami pengguna sistem.

2. Sistem ini memberikan informasi kepada pengguna sistem terhadap kemungkinan tingkat resiko tipe penyakit Diabetes Melitus berdasarkan nilai kepercayaan atau densitas terbesar. Tingkat akurasi sistem berdasarkan hasil uji coba dan pengujian terhadap data didapatkan prosentase sebesar $86.7 \%$.

5.2 Saran

Pada penelitian ini ada beberapa saran yang perlu diberikan, meliputi :

1. Aplikasi sistem pakar yang dibangun bisa dikembangkan menggunakan metode selain Dempster Shafer.

2. Parameter yang digunakan untuk menegakkan diagnosa pada sistem bisa menggunakan parameter selain yang digunakan pada sistem ini.

\section{Daftar Pustaka:}

Kusumadewi, Sri. 2003. Artificial Intelligence (Teknik dan Aplikasinya). Yogyakarta: Graha Ilmu

Rikhiana, Esthi. dan Fadlil, Abdul. 2013. "Implementasi Sistem Pakar Untuk Mendiagnosa Penyakit Dalam Pada Manusia Menggunakan Metode Dempster Shafer". Jurnal Sarjana Teknik Informatika. 1(1), 3.

S, A, Rosa. Dan Shalahuddim, M. 2013. Rekayasa Perangkat Lunak Terstruktur dan Berorientasi Objek. Bandung: Informatika

Sulistyohati, Aprilia dan Hidayat Taufiq. 2008. "Aplikasi Sistem Pakar Diagnosa Penyakit Ginjal Dengan Metode Dempster-Shafer". Seminar Nasional Aplikasi Teknologi Informasi.

Sutojo, T., dkk. 2011. Kecerdasan Buatan. Yogyakarta: Penerbit ANDI 
Suyono, Slamet., dkk. 1995. Penatalaksanaan Diabetes Melitus Terpadu. Edisi Kedua. Jakarta: Balai Penerbit FKUI

Wahyuni, Elyza G. dan Prijodiprojo Widodo. 2013. "Prototype Sistem Pakar untuk Mendeteksi Tingkat Resiko Penyakit Jantung Koroner dengan Metode Dempster-Shafer (Studi Kasus: RS. PKU Muhammadiyah Yogyakarta)". IJCCS. 7(2), 133-144 